\title{
Detection and Characterization of Methionine Oxidation in Peptides by Collision-Induced Dissociation and Electron Capture Dissociation
}

\author{
Ziqiang Guan, Nathan A. Yates, and Ray Bakhtiar \\ Merck Research Laboratories, Rahway, New Jersey, USA
}

\begin{abstract}
Electron capture dissociation (ECD) and collision-induced dissociation (CID), the two complementary fragmentation techniques, are demonstrated to be effective in the detection and localization of the methionine sulfoxide $[\operatorname{Met}(\mathrm{O})]$ residues in peptides using Fourier transform ion cyclotron resonance (FTICR) mass spectrometry. The presence of $\operatorname{Met}(\mathrm{O})$ can be easily recognized in the low-energy CID spectrum showing the characteristic loss of methanesulfenic acid $\left(\mathrm{CH}_{3} \mathrm{SOH}, 64 \mathrm{Da}\right)$ from the side chain of $\operatorname{Met}(\mathrm{O})$. The position of $\operatorname{Met}(\mathrm{O})$ can then be localized by ECD which is capable of providing extensive peptide backbone fragmentation without detaching the labile $\operatorname{Met}(\mathrm{O})$ side chain. We studied $C I D$ and ECD of several $\operatorname{Met}(\mathrm{O})$-containing peptides that included the 44-residue human growth hormone-releasing factor (GRF) and the human atrial natriuretic peptide (ANP). The distinction and complementarity of the two fragmentation techniques were particularly remarkable in their effects on ANP, a disulfide bond-containing peptide. While the predominant fragmentation pathway in CID of ANP was the loss of $\mathrm{CH}_{3} \mathrm{SOH}$ (64 Da) from the molecular ion, ECD of ANP resulted in many sequence-informative products, including those from cleavages within the disulfidebonded cyclic structure, to allow for the direct localization of $\operatorname{Met}(\mathrm{O})$ without the typical procedures for disulfide bond reduction followed by $-\mathrm{SH}$ alkylation. (J Am Soc Mass Spectrom 2003, 14, 605-613) (C) 2003 American Society for Mass Spectrometry
\end{abstract}

$\mathrm{M}$ ethionine (Met) has a sulfur-containing side chain that is susceptible to oxidation. Met oxidation in proteins plays a prominent role in aging and age-related degenerative diseases [1-4]. Met oxidation in calmodulin results in its impaired function in calcium signaling, which is associated with the loss of calcium homeostasis in aged brain $[5,6]$. The oxidation of Met-35 in the $\beta$-amyloid peptide (A $\beta$ ) contributes to the insolubility and stability of $\mathrm{A} \beta$, and has implications in Alzheimer's disease [7, 8]. However, increasing evidence also suggests that Met oxidation is an important mechanism in cellular regulation. Under physiological conditions, the oxidation of Met to methionine sulfoxide $[\operatorname{Met}(\mathrm{O})]$ can be reduced (to Met) by methionine sulfoxide reductase (MSRA). The Met oxidation-reduction process has been found to play a key role in the activation-deactivation cycle of several crucial signaling proteins and the maintenance of homeostatic balance in physiological systems $[9,10]$. Hoshi and co-workers showed that the methionine oxidationreduction process modulates the activities of potassium channel proteins, which play key roles in the cellular

Published online April 24, 2003

Address reprint requests to Dr. Z. Guan, Department of Molecular Profiling, Merck Research Laboratories, P.O. Box 2000, RY50-105, Rahway, NJ 07065, USA. E-mail: ziqiang_guan@merck.com signal transduction activities of excitable cells in the brain, heart and muscle [11].

Despite its significance in cellular functions and implications for various pathological conditions, Met oxidation has been largely overlooked in protein structural characterization. This is partly due to the fact that methionine sulfoxide residues are reduced, and detected as methionines in traditional Edman sequencing procedures [12, 13]. In addition, Met oxidation can be artificially introduced during sample preparation, purification and analysis $[14,15,20]$, which presents another degree of complexity in characterization of Met oxidation in proteins.

Several mass spectrometry (MS)-based methods have recently been introduced to characterize $\operatorname{Met}(\mathrm{O})$ in proteins and peptides, overcoming the limitations of the conventional protein analysis methods, such as Edman degradation, gel electrophoresis and amino acid analysis [13-23]. Among the MS-based techniques, tandem MS (MS/MS) [24] is particularly attractive; the peptide sequence and the position of $\operatorname{Met}(\mathrm{O})$ can be directly determined through the gas-phase fragmentation [14], usually through collision-induced dissociation (CID) (a popular technique currently implemented on most commercial MS/MS instruments). A distinct fragmentation pathway in CID of $\operatorname{Met}(\mathrm{O})$-containing peptides is the neutral loss of $64 \mathrm{Da}$ from the precursor and/or product ions $[14,15,18]$. The characteristic neutral loss 


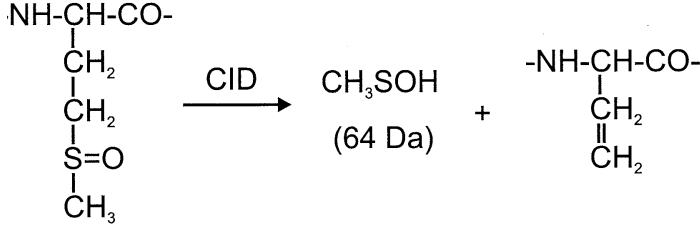

Scheme 1

of $64 \mathrm{Da}$ corresponds to the ejection of methanesulfenic acid $\left(\mathrm{CH}_{3} \mathrm{SOH}, 64 \mathrm{Da}\right)$ from the side chain of $\operatorname{Met}(\mathrm{O})$ (Scheme 1) [18, 28]. The loss of $64 \mathrm{Da}$ is unique, in proteins and peptides, to $\operatorname{Met}(\mathrm{O})$, and is particularly useful in differentiating between $\operatorname{Met}(\mathrm{O})$ and phenylalanine (both residues have the same nominal mass of 147 Da) in MS/MS peptide sequencing. However, this lowenergy pathway can further inhibit the backbone sequence fragmentation by CID, especially for larger polypeptides. In fact, the complete MS/MS characterization of Met(O) using CID has so far been limited to small peptides, such as those from enzymatic digestion $[14,15]$.

Electron capture dissociation (ECD) [29-35] has recently emerged as a powerful alternative in MS/MS of multiply charged proteins and peptides generated by electrospray ionization (ESI) [36] using Fourier transform ion cyclotron resonance (FTICR) mass spectrometry [37]. ECD, a technique based on partial neutralization of multiply-protonated ions with electrons, typically renders extensive inter-residue backbone cleavage to yield $c$ and $z \cdot$ fragment ions, in contrast to the $b$ and $y$ fragment ions produced from the amide bond cleavage by conventional energetic fragmentation methods, including CID and infrared multiphoton dissociation (IRMPD) [25-27, 38]. Furthermore, ECD is a nonergodic fragmentation technique, i.e., the intramolecular energy randomization is slower than the ECD cleavage processes. This unique nonergodic feature has been exemplified by the ability of ECD in preserving the labile side chain modifications groups on the peptide backbone fragments [39-44], in contrast to CID and other conventional fragmentation techniques which typically eject the labile modifications first, as does the loss of $\mathrm{CH}_{3} \mathrm{SOH}$ from $\operatorname{Met}(\mathrm{O})$.

Herein, we demonstrate that the combined data from CID and ECD spectra can be used to quickly detect and localize the $\operatorname{Met}(\mathrm{O})$ residues in a series of peptides, including one with an internal disulfide bond.

\section{Experimental}

High purity solvents were purchased from Fisher Scientific (Springfield, NJ). Peptides were obtained from Bachem Biosciences Inc. (King of Prussia, PA) and used without additional purification. Hydrogen peroxide $\left(\mathrm{H}_{2} \mathrm{O}_{2}\right)$ was obtained from Sigma (St. Louis, MO). The oxidized form of $\beta$-MSH was prepared by reaction with equal molar concentration (1:1) of hydrogen peroxide at $37^{\circ} \mathrm{C}$ for $30 \mathrm{~min}$. Samples were dissolved in water/ methanol/acetic acid (49:49:2, vol/vol/vol) at a concentration of $5 \mu \mathrm{M}$, and were nanosprayed [45] from the PicoTips (New Objective, Inc., Woburn, MA).

In order to perform ECD experiments, the 3 tesla Finnigan NewStar Fourier transform ion cyclotron resonance mass spectrometer (Finnigan FT/MS, Bremen, Germany) was modified. The electron gun assembly on the commercial instrument was removed, and installed in the fringing magnetic field region $(\sim 0.8 \mathrm{~m}$ away from the ICR cell) on the side opposite to that of the ESI source. Ions generated by nanospray were externally accumulated outside of the magnet in a rf-only octopole for $1 \mathrm{~s}$ and then transferred through electrostatic lenses into the trapped ion cell [46]. The precursor ions were first isolated by stored-waveform inverse Fourier transform (SWIFT) ejection [47]. Subsequent to a short pulse of $\mathrm{N}_{2}$ collision gas for ion cooling, the isolated ions were irradiated with low-energy $(0.5 \mathrm{eV})$ electrons from the heated-filament of the electron gun for $1 \mathrm{~s}$. The product ions were then subjected to chirp excitation and broadband detection. Generally, an average of 50 time-domain transients was obtained with an Odyssey data system.

In sustained off-resonance irradiation (SORI) [48] CID experiments, the SWIFT-isolated precursor ions were collisionally activated using $\sim 20 \mathrm{~V}_{p-p}$ sustained off-resonance irradiation at $-1.5 \mathrm{kHz}$ off-resonance from the frequency of precursor ion, $0.1 \mathrm{~s}$ after the pulsed introduction of $\mathrm{N}_{2}$ collision gas (a peak pressure reached $\sim 5 \times 10^{-6}$ torr in the analyzer vacuum chamber).

CID experiments were also performed on the LCQ Deca (ThermoFinnigan Co., San Jose, CA), a quadrupole ion trap mass spectrometer equipped with an ESI source. The voltage of electrospray needle was set at 4.5 $\mathrm{kV}$. The heated capillary was maintained at $250{ }^{\circ} \mathrm{C}$ and held at a potential of $14 \mathrm{~V}$. For all ion-trap MS/MS experiments, the relative collision energy was set at $30 \%$ $\left(\mathrm{V}_{p-p} \sim 0.4-1.0 \mathrm{~V}\right)$, depending on the mass of the precursor ions.

\section{Results and Discussion}

\section{Adrenocorticotropic Hormone (ACTH) Fragment 4-9}

Among the several CID techniques developed in FTICR, sustained off-resonance irradiation (SORI) [48] has the highest fragmentation efficiency for dissociating multiply charged peptides and proteins [27]. Figure 1a is the SORI-CID spectrum of $[\mathrm{M}+2 \mathrm{H}]^{2+}$ of the Metoxidized ACTH 4-9, M(O)EHFKF, showing the typical $y$ - and $b$-type fragments by CID. The molecular ion $[\mathrm{M}+2 \mathrm{H}]^{2+}$ and the product ions $b_{4}$ and $b_{5}$ are accompanied by the loss of $\mathrm{CH}_{3} \mathrm{SOH}$ (64 Da); the averaged exact mass of 64.002 is consistent with $\mathrm{CH}_{3} \mathrm{SOH}$ (calculated mass 63.998). The fragmentation map shown in Figure 1a indicates that the SORI-CID spectrum alone 


\section{a) CID}
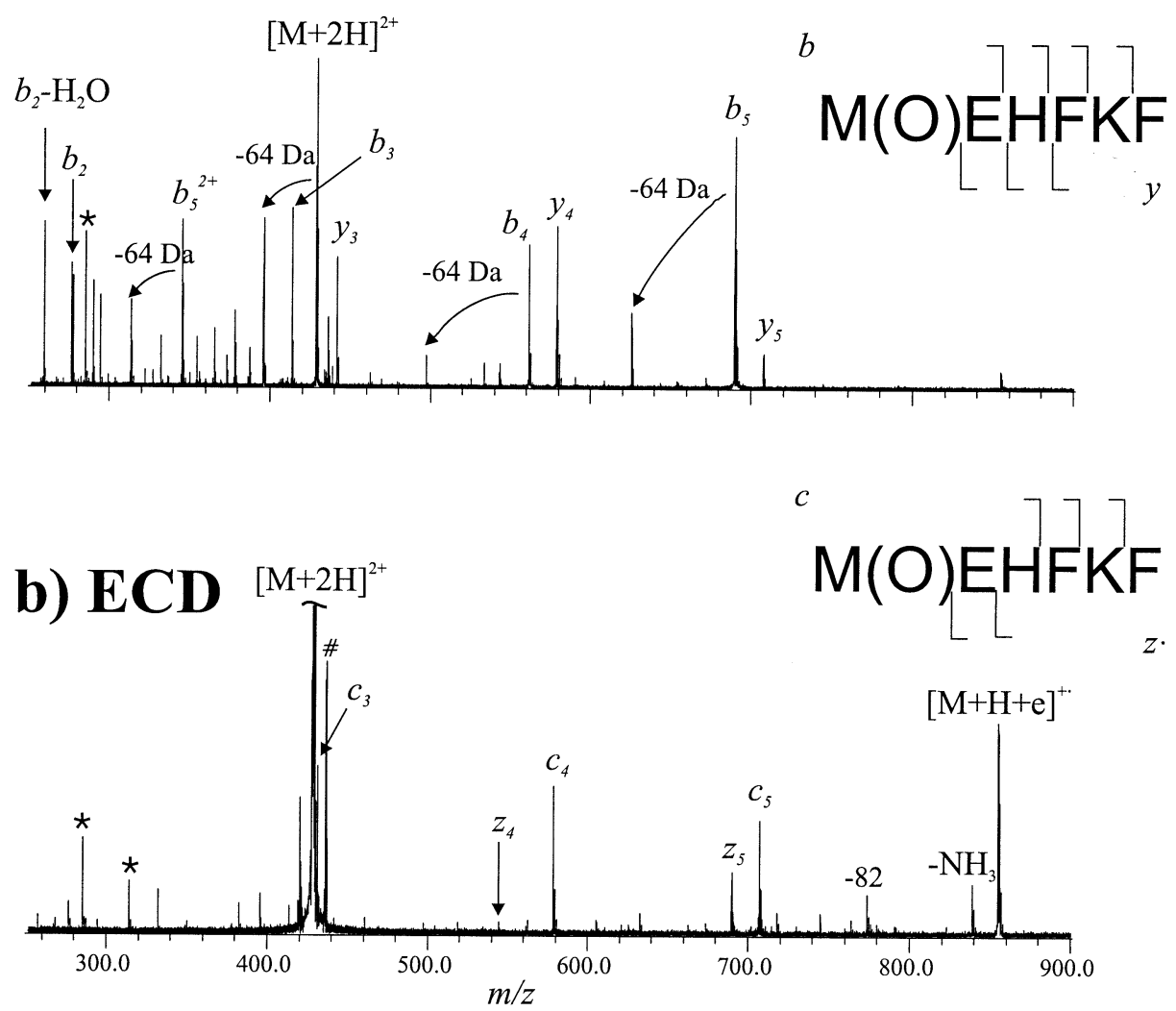

Figure 1. (a) SORI-CID and (b) ECD FTICR spectra of SWIFT-isolated $[\mathrm{M}+2 \mathrm{H}]^{2+}$ of M(O)EHFKF. The noise signals are marked with an asterisk. The peak with the number sign is an adduct species not removed by SWIFT excitation.

contains all information for detecting and localizing the $\operatorname{Met}(\mathrm{O})$ in this small peptide. For comparison, CID was also performed on a quadrupole ion trap MS (LCQ Deca), the resulting spectrum (not shown) was very similar to that of SORI-CID on FTICR, showing the same $y$ - and $b$-ions as well as the losses of $64 \mathrm{Da}$ from both $[\mathrm{M}+2 \mathrm{H}]^{2+}$ and the product ions $\left(b_{4}\right.$ and $\left.b_{5}\right)$. In contrast, the ECD spectrum (Figure $1 \mathrm{~b}$ ) shows the amine bond cleavage products, $c_{3}, c_{4}, c_{5}, z_{4}$, and $z_{5}$, as well as the abundant charge-reduced ion $[\mathrm{M}+\mathrm{H}+\mathrm{e}]^{+*}$. No loss of $64 \mathrm{Da}$ from the molecular or product ions is observed in the ECD spectrum. The retention of the labile side chain of $\operatorname{Met}(\mathrm{O})$ on the backbone fragment ions is attributed to the nonergodic nature of ECD [29-33], and is consistent with the ECD results on other labile post-translational modifications [39-44]. Besides the $c, z$ p product ions, the losses of $\mathrm{NH}_{3}$ and $82 \mathrm{Da}$ (the side chain loss of histidine residue [49]) are also observed.

\section{Human Growth Hormone-Releasing Factor (GRF)}

SORI-CID of the Met-oxidized human GRF only yields limited backbone fragmentation (Figure 2a), with 12 out of total 43 inter-residue bonds being cleaved. The most abundant product ions $\left(b_{25}^{3+}, b_{37}^{4+}, y_{11}^{3+}\right.$, and $\left.y_{19}^{4+}\right)$ arise from the cleavages at the $\mathrm{C}$-terminal sides of asparic acid (D) and glutamic acid (E) residues, the favorable cleavage sites in CID. The peaks corresponding to the loss of $\mathrm{CH}_{3} \mathrm{SOH}(64 \mathrm{Da})$ from $[\mathrm{M}+7 \mathrm{H}]^{7+}$ and three product ions $\left(y_{19}^{4+}, y_{42}^{6+}\right.$, and $\left.b_{37}^{4+}\right)$ are observed. In contrast, ECD offers far more extensive backbone fragmentation (Figure $2 b$ ), with 41 of the total 43 inter-residue bonds being cleaved. Of the $c, z \cdot$ fragment ions, 32 are complementary pairs whose masses sum to that of the molecular ion. No loss of $64 \mathrm{Da}$ is observed. The position of $\operatorname{Met}(\mathrm{O})-27$ can be unequivocally determined by the two complementary pairs of ECD product ions, $c_{26}^{3+} / z_{18}^{2+\cdot}$ and $c_{27}^{3+} / z_{17}^{2+\cdot}$. The product maps of CID and ECD are summarized in Figure 3.

\section{$\beta$-Melanocyte-Stimulating Hormone ( $\beta-M S H)$}

CID and ECD experiments were performed on both the native (reduced) $\beta-\mathrm{MSH}$ and the Met-oxidized $\beta-\mathrm{MSH}(\mathrm{O})$. $[\mathrm{M}+4 \mathrm{H}]^{4+}$ at $m / z 665.8$ for $\beta-\mathrm{MSH}(\mathrm{Mr}=$ $2659.2)$, and $[\mathrm{M}+4 \mathrm{H}]^{4+}$ at $m / z 669.8$ for $\beta-\mathrm{MSH}(\mathrm{O})$ $(\mathrm{Mr}=2675.2)$ are dominant signals in their full-scan MS spectra. The mass increase of $16 \mathrm{Da}$ for $\beta-\mathrm{MSH}(\mathrm{O})$ indicates that the one oxygen atom has been added by 
a) CID

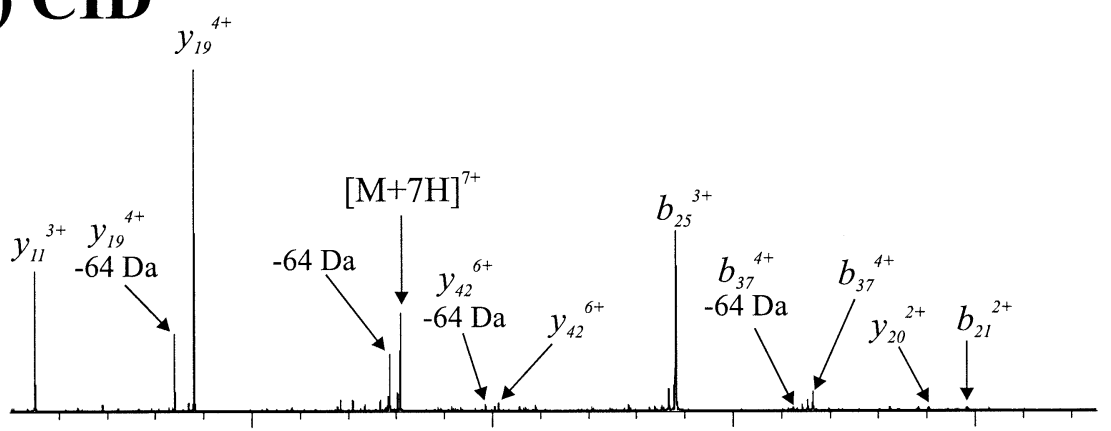

b) $\mathrm{ECD}$

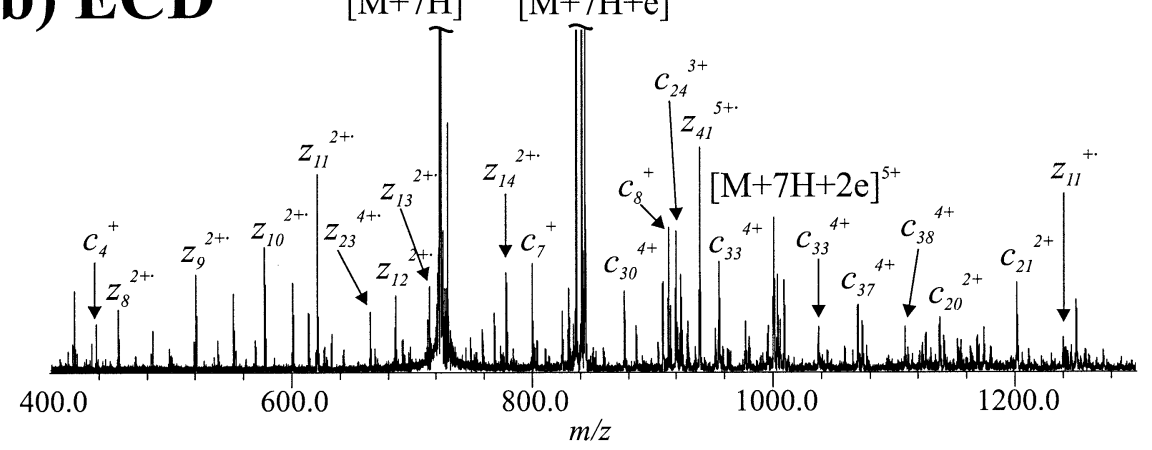

Figure 2. (a) SORI-CID and (b) ECD FTICR spectra of SWIFT-isolated $[\mathrm{M}+7 \mathrm{H}]^{7+}$ of the Met-oxidized human growth hormone-releasing factor (GRF).

the oxidation reaction. SORI-CID of the $\mathrm{MSH}(\mathrm{O})$ resulted in the typical elimination of 64 Da from [M + $4 \mathrm{H}]^{4+}$ and several product ions (data not shown). The ECD spectra obtained for $[\mathrm{M}+4 \mathrm{H}]^{4+}$ of the $\beta-\mathrm{MSH}$ and $\beta-\mathrm{MSH}(\mathrm{O})$ are shown in Figure $4 \mathrm{a}$ and $\mathrm{b}$. As shown in the inset of Figure $4 b$, ECD cleaved all inter-residue bonds of $\beta-\mathrm{MSH}(\mathrm{O})$, except for the $\mathrm{N}$-terminal sides of three proline residues, which are impervious to the ECD due to the cyclic structure of proline [29-33]. The expanded ECD spectra of $\beta-\mathrm{MSH}$ and $\beta-\mathrm{MSH}(\mathrm{O})$ (Fig- ure 4c) show that the position of $\operatorname{Met}(\mathrm{O})-11$ can be unequivocally determined from the mass shifts (16 Da for one oxygen atom) of $c_{12}^{2+}$ and $z_{12}^{2+\cdot}$ ions.

\section{Atrial Natriuretic Peptide (ANP)}

The human ANP is a 28 amino acid peptide with a 17 amino acid ring closed by a disulfide bond between Cys-7 and Cys-23. The structure of Met-oxidized $\mathrm{ANP}(\mathrm{O})$ is: SLRRSSCFGGRM(O)DRIGAQSGLGCNSFRY. The pre-

\section{CID:

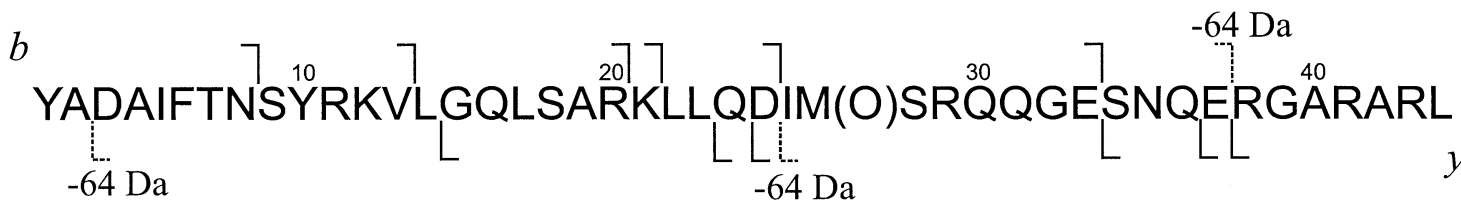

\section{ECD:}

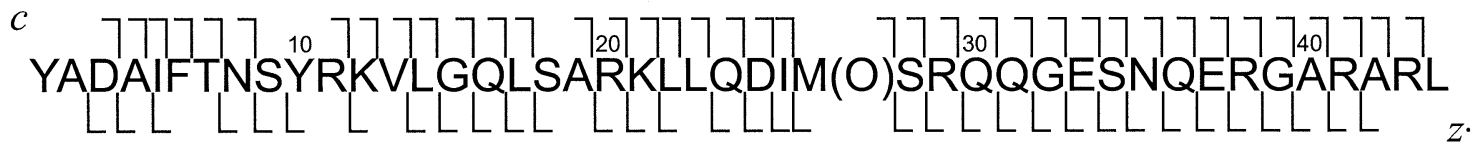

Figure 3. Product maps indicating the cleavage sites in SORI-CID and ECD of the human growth hormone-releasing factor (GRF). 


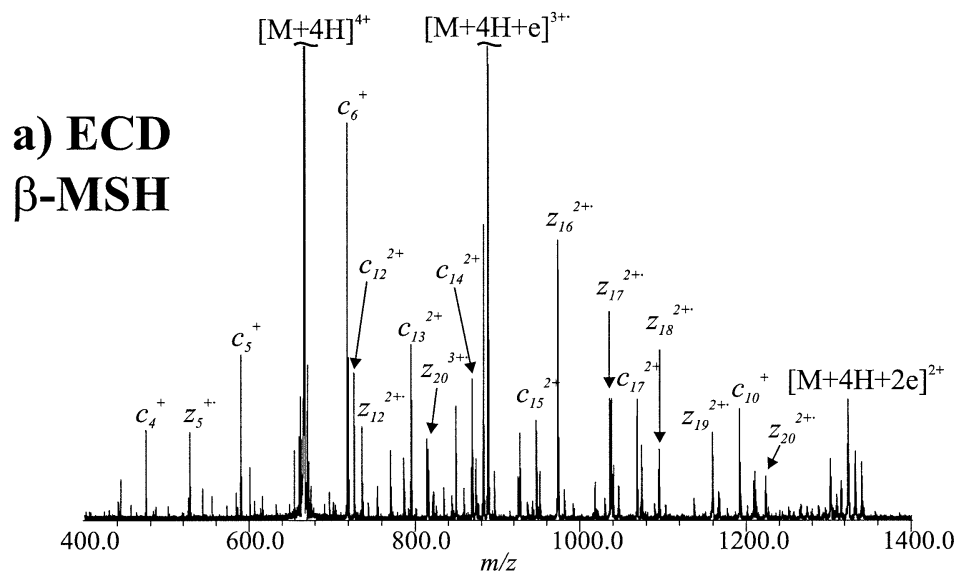

c) $\mathbf{E C D}$

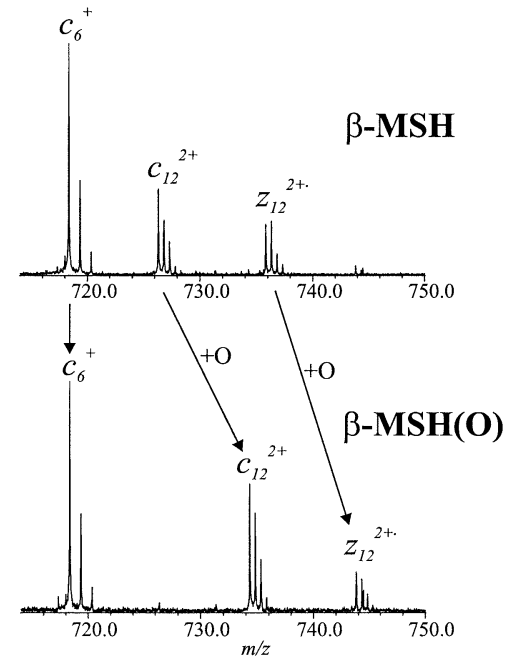

b) $\mathrm{ECD}$ $\beta-\operatorname{MSH}(\mathbf{O})$

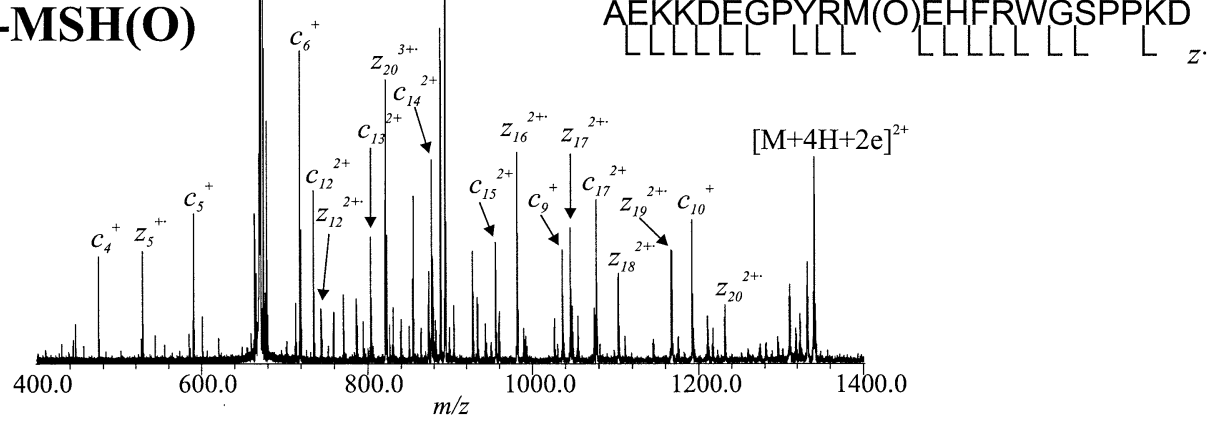

Figure 4. ECD FTICR spectra of SWIFT-isolated $[\mathrm{M}+4 \mathrm{H}]^{4+}$ of (a) $\beta-\mathrm{MSH}$ and (b) $\beta-\mathrm{MSH}(\mathrm{O})$. (c) The expanded ECD spectra showing the mass shifts of $c_{12}^{2+}$ and $z_{12}^{2+\cdot}$ in $\beta-\mathrm{MSH}$ and $\beta-\mathrm{MSH}(\mathrm{O})$. ECD product map of $\beta-\mathrm{MSH}(\mathrm{O})$ is depicted in (b).

dominant fragmentation pathway in SORI-CID of $\mathrm{ANP}(\mathrm{O})$ is the loss of $\mathrm{CH}_{3} \mathrm{SOH}(64 \mathrm{Da})$ from the molecular ion $[\mathrm{M}+5 \mathrm{H}]^{5+}$ (Figure 5a). No appreciable backbone fragmentation or disulfide bond cleavage is observed in the CID spectrum. It is well known that disulfide bonds are generally resistant to cleavage by low-energy CID [50], thus reduction of disulfide bonds with dithiothreitol (DTT) followed by -SH alkylation is necessary before MS/MS analysis. ECD of ANP, however, resulted in 14 backbone cleavages, including six from within the cyclic structure. Each of the product ions from cleavages within the cyclic structure $\left(c_{10}, c_{12}\right.$, $c_{16}, c_{18}, c_{19}, z_{10}, z_{11}$, and $z_{12}$ ) arises from ECD cleavage of two bonds: A backbone amine bond and a disulfide bond. None of the $\operatorname{Met}(\mathrm{O})$-containing products $\left(c_{12}, c_{16}\right.$, $c_{18}$, and $c_{19}$ ) is accompanied by the loss of $\mathrm{CH}_{3} \mathrm{SOH}(64$ $\mathrm{Da}$ ). The ability to cleave disulfide bonds is a distinctive feature of ECD. In fact, the disulfide bond cleavage is favored over backbone bond cleavage in ECD [30]. The mechanism for the disulfide bond cleavage by ECD is still under investigation. It has been suggested by McLafferty and co-workers that disulfide bond cleavage is likely due to the high affinity of the -S-S- site for the H.atom (from neutralization of a proton by electron capture), to form a hypervalent intermediate that rapidly lead to the dissociation of disulfide bond [30]. The gas-phase disulfide bond cleavage by ECD holds the promise of direct sequencing of disulfide-containing peptides by MS/MS, thus eliminating the need for timeand material-consuming procedures of disulfide reduction and $-\mathrm{SH}$ alkylation.

\section{$\left[\right.$ Sar $\left.^{9}, \operatorname{Met}(\mathrm{O} 2)^{11}\right]$-Substance P}

Methionine sulfone $\left(\mathrm{MetO}_{2}\right)$ can be formed from $\mathrm{Met}(\mathrm{O})$ in the presence of a strong oxidant. $\mathrm{MetO}_{2}$ is very stable, and is biologically irreversible [9]. The SORI-CID spectrum (Figure 6a) shows the typical $b$ and $y$ fragment ions, with some being accompanied by $\mathrm{H}_{2} \mathrm{O}$ and $\mathrm{NH}_{3}$ losses. In contrast to $\operatorname{Met}(\mathrm{O})$, no diagnostic neural loss indicative of $\mathrm{MetO}_{2}$ is observed, which has been noted previously [14]. ECD cleaves all inter-residue bonds, except for the $\mathrm{N}$-terminal sides of the two prolines. The ECD fragmentation pattern (Figure 6b) of this modified substance $\mathrm{P}$ is very similar to that of the native substance P (RPKPQQFFGLM-NH ${ }_{2}$ ) [51]. Note Sar [Sar- 

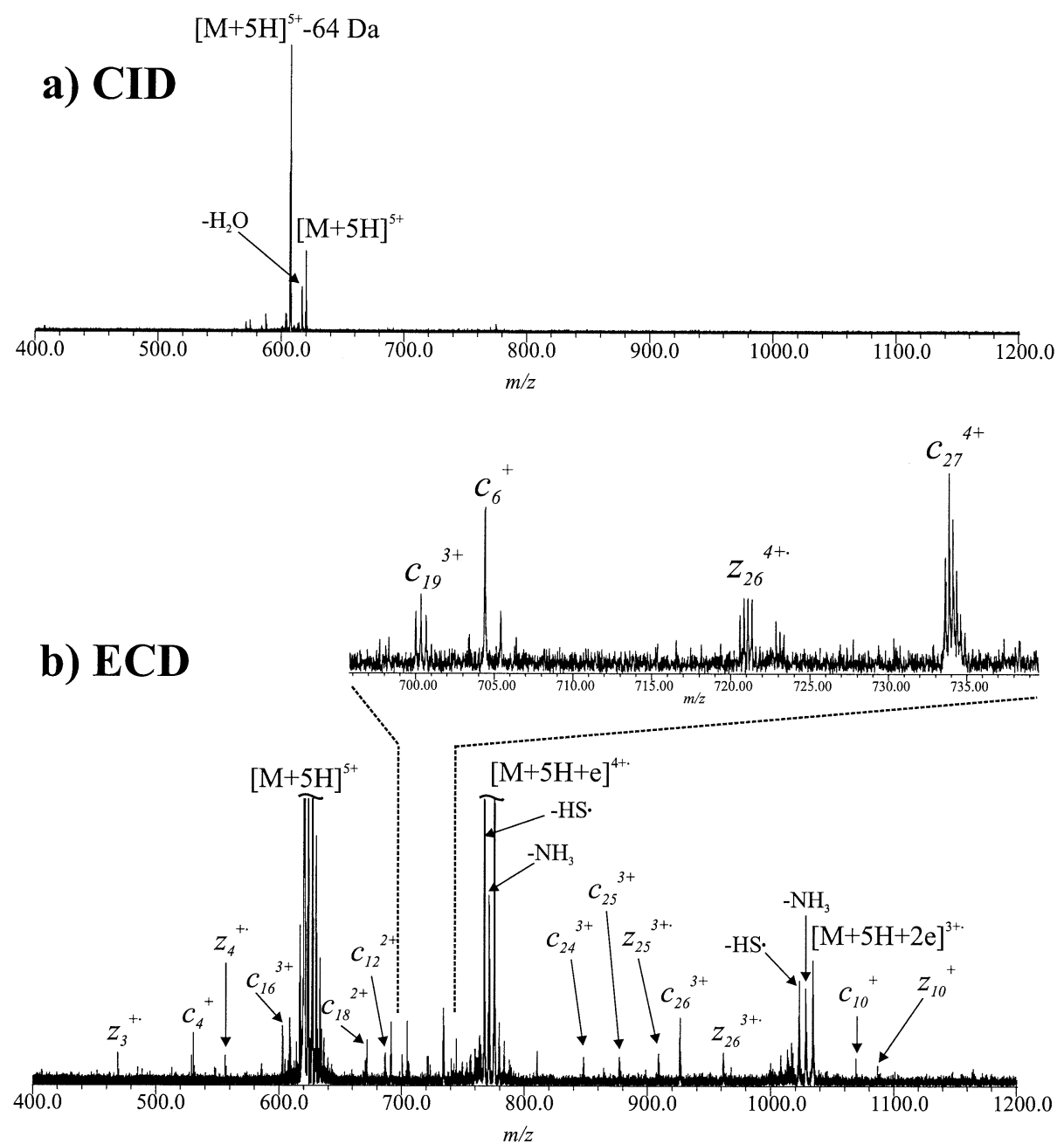

c)

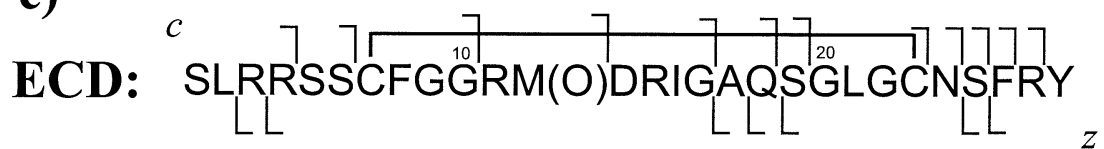

Figure 5. (a) SORI-CID and (b) ECD spectra of SWIFT-isolated $[\mathrm{M}+5 \mathrm{H}]^{5+}$ of $\mathrm{ANP}(\mathrm{O})$. The isotopic resolution as shown in the zoom view of the ECD spectrum is crucial in determining the charge states and identifying the product ions. (c) ECD product map of $\mathrm{ANP}(\mathrm{O})$.

cosine: $-\mathrm{N}\left(\mathrm{CH}_{3}\right)-\mathrm{CH}_{2}-\mathrm{CO}-$ ] is the only other amino acid (besides proline) with a backbone tertiary nitrogen in a peptide that has been studied by ECD. The presence of $c_{9}$ ion indicates the cleavage of the $\mathrm{N}$-terminal side of Sar, supporting the explanation given by McLafferty and co-workers [30,31] for why the N-terminal side of proline can not be cleaved by ECD: The $\mathrm{N}-\mathrm{C}_{\alpha}$ bond in proline may indeed be cleaved by ECD, but the peptide backbone is still connected through the proline side chain.

\section{Conclusions}

ECD and CAD are complementary fragmentation techniques that provide "easy-to-interpret" spectra for quickly identifying and localizing the $\operatorname{Met}(\mathrm{O})$ residues in peptides. The characteristic elimination of $\mathrm{CH}_{3} \mathrm{SOH}(64 \mathrm{Da})$ in CID serves as a signature tag for the presence of $\operatorname{Met}(\mathrm{O})$ in peptides. ECD then offers extensive backbone fragmentation without detaching the labile side chain, to allow for the direct localization of the $\operatorname{Met}(\mathrm{O})$ residues. The accurate mass measurement of FTICR/MS can also assist in the unequivocal determination of Phe and $\operatorname{Met}(\mathrm{O})$, as these two residues share the same nominal mass (147 Da) but differ in exact mass by $0.033 \mathrm{Da}$ (Phe, 147.0684; $\operatorname{Met}(\mathrm{O}), 147.0354)$. With higher magnetic field FTICR instruments, the approach described here should be equally applicable to identify and localize methionine oxidation in proteins, helping to better understand 


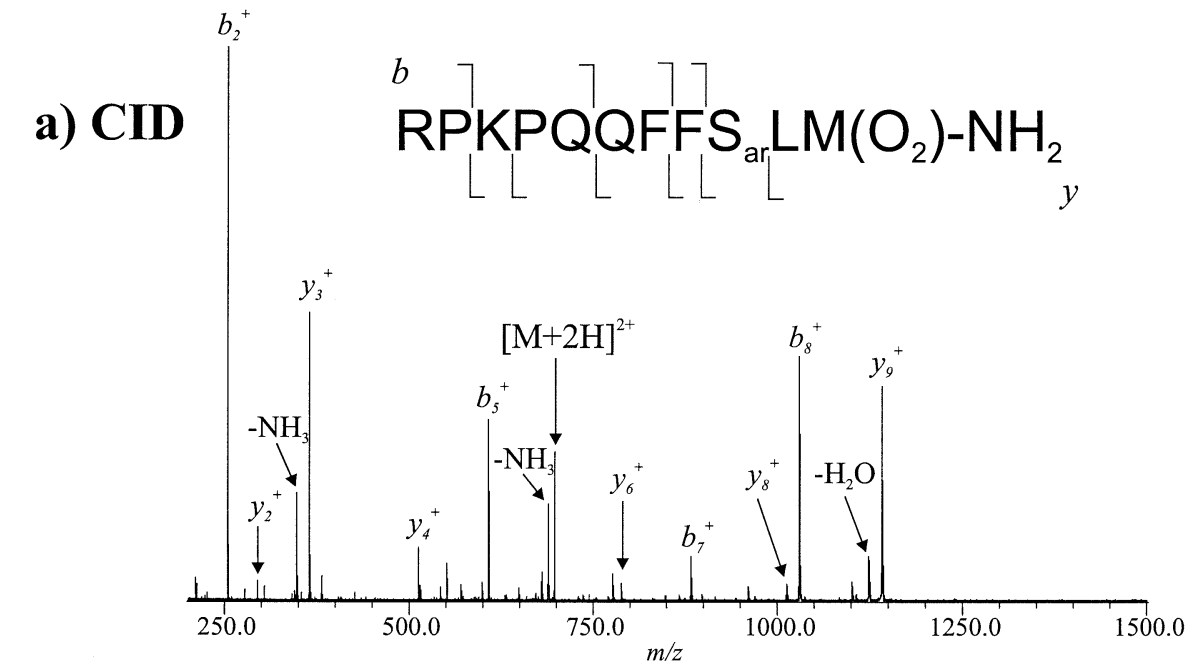

b) $\mathrm{ECD}$
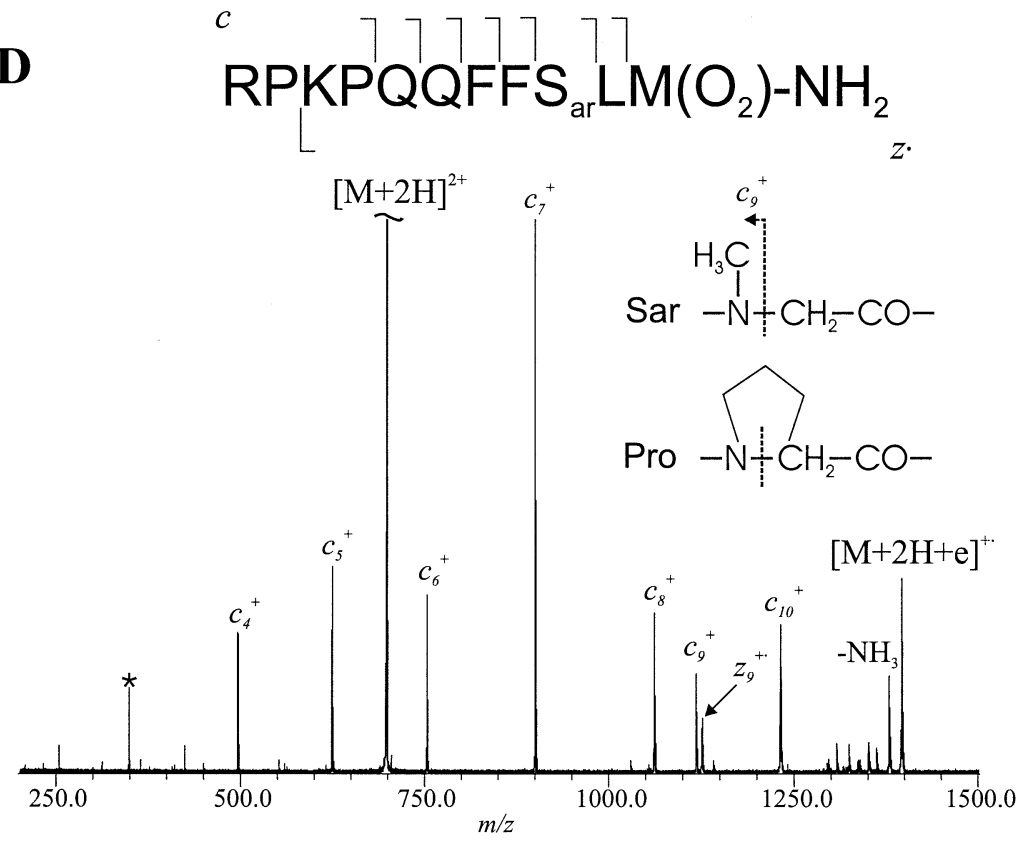

Figure 6. (a) SORI-CID and (b) ECD FTICR spectra of $\left[\operatorname{Sar}^{9}, \operatorname{Met}(\mathrm{O} 2)^{11}\right]$-substance P.

the physiological and pathological roles of this overlooked post-translational modification.

\section{Acknowledgments}

The authors are grateful to Dr. Ronald B. Franklin for his kind support and helpful discussion, and to Dr. Shilan Wu for critical reading of the manuscript.

\section{References}

1. Berlett, B. S.; Stadtman, E. R. Protein Oxidation in Aging, Disease, and Oxidative Stress. J. Biol. Chem. 1997, 272(33), 20313-20316.

2. Stadtman, E. R.; Levine, R. L. Protein Oxidation. Annu. N.Y. Acad. Sci. 2000, 899, 191-208.
3. Stadtman, E. R.; Berlett, B. S. Reactive Oxygen-Mediated Protein Oxidation in Aging and Disease. Chem. Res. Toxicol. 1997, 10(5), 485-494.

4. Vogt, W. Oxidation of Methionyl Residues in Proteins: Tools, Targets, and Reversal. Free Rad. Biol. Med. 1995, 18, 93-105.

5. Gao, J.; Yin, D. H.; Yao, Y.; Sun, H.; Qin, Z.; Schöneich, C.; Williams, T. D.; Squier, T. C. Loss of Conformational Stability in Calmodulin Upon Methionine Oxidation. Biophys. J. 1998, 74, 1115-1134.

6. Gao, J.; Yin, D.; Yao, Y.; Williams, T. D.; Squier, T. C. Progressive Decline in the Ability of Calmodulin Isolated from Aged Brain to Activate the Plasma Membrane Ca-ATPase. Biochemistry 1998, 37, 9536-9548.

7. Palmblad, M.; Westlind-Danielsson, A.; Bergquist, J. Oxidation of Methionine 35 Attenuates Formation of Amyloid $\beta$-Peptide 1-40 Oligomers. J. Biol. Chem. 2002, 277, 1950619510. 
8. Kuo, Y.-M.; Webster, S.; Emmerling, M. R.; De Lima, N.; Roher, A. E. Irreversible Dimerization/Tetramerization and Post-translational Modifications Inhibit Proteolytic Degradation of A $\beta$ Peptides of Alzheimer's Disease. Biochim. Biophys. Acta 1998, 1406, 291-296.

9. Hoshi, T.; Heinemann, S. H. Regulation of Cell Function by Methionine Oxidation and Reduction. J. Physiol. 2001, 531, $1-11$.

10. Stadtman, E. R.; Moskovitz, J.; Berlett, B. S.; Levine, R. L. Cyclic Oxidation and Reduction of Protein Methionine Residues is an Important Antioxidant Mechanism. Mol. Cell. Biochem. 2002, 234/235, 3-9.

11. Ciorba, M. A.; Heinemann, S. H.; Weissbach, H.; Brot, N.; Hoshi, T. Modulation of Potassium Channel Function by Methionine Oxidation and Reduction. Proc. Natl. Acad. Sci. U.S.A. 1997, 94, 9932-9937.

12. Marki, W.; Spiess, J.; Tache, Y.; Rivier, J. E. Total Solid-Phase Synthesis of Porcine Gut Gastrin Releasing Peptide (GRP), a Mammalian Bombesin. J. Am. Chem. Soc. 1981, 103, 3178-3185.

13. Asano, T.; Ashida, M. Transepithelially Transported ProPhenoloxidase in the Cuticle of the Silkworm. Bombyx mori. J. Biol. Chem. 2001, 276, 11113-11125.

14. Schey, K. L.; Finley, E. L. Identification of Peptide Oxidation by Tandem Mass Spectrometry. Acc. Chem. Res. 2000, 33, 299-306.

15. Lagerwerf, F. M.; van de Weert, M.; Heerma, W.; Haverkamp, J. Identification of Oxidized Methionine Peptides. Rapid Commun. Mass Spectrom. 1996, 10, 1905-1910.

16. Morand, K.; Talbo, G.; Mann, M. Oxidation of Peptides During Electrospray Ionization. Rapid Commun. Mass Spectrom. 1993, 7, $738-743$.

17. Griffiths, S. W.; Cooney, C. L. Development of a Peptide Mapping Procedure to Identify and Quantify Methionine Oxidation in Recombinant Human $\alpha 1$-Antitrypsin. J. Chromatogr. A 2002, 942, 133-143.

18. Jiang, X.; Smith, J. B.; Abraham, E. C. Identification of a MS-MS Fragment Diagnostic for Methionine Sulfoxide. J. Mass Spectrum. 1996, 31, 1309-1310.

19. Smith, J. B.; Jiang, X.; Abraham, E. C. Identification of Hydrogen Peroxide Oxidation Sites of $\alpha \mathrm{A}$ - and $\alpha \mathrm{B}$-Crystallins. Free Rad. Res. 1997, 26, 103-111.

20. Steen, H.; Mann, M. Similarity Between Condensed Phase and Gas Phase Chemistry: Fragmentation of Peptides Containing Oxidized Cysteine Residues and Its Implications for Proteomics. J. Am. Soc. Mass Spectrom. 2001, 12, 228-232.

21. Kotiaho, T.; Eberlin, M. N.; Vainiotalo, P.; Kostianinen, R. Electrospray Mass and Tandem Mass Spectrometry Identification of Ozone Oxidation Products of Amino Acids and Small Peptides. J. Am. Soc. Mass Spectrom. 2000, 11, 526-535.

22. Zhu, H.; Hunter, T. C.; Pan, S.; Yau, P. M.; Bradbury, E. M.; Chen, X. Residue-Specific Mass Signatures for the Efficient Detection of Protein Modifications by Mass Spectrometry. Anal. Chem. 2002, 74, 1687-1694.

23. Hollemeyer, K.; Heinzle, E.; Tholey, A. Identification of Oxidized Methionine Residues in Peptides Containing Two Methionine Residues by Derivatization and Matrix-Assisted Laser Desorption/Ionization Mass Spectrometry. Proteomics 2002, 2, 1524-1531.

24. Busch, K. L.; Glish, G. L.; McLuckey, S. A. Mass Spectrometry/ Mass Spectometry. Techniques and Applications of Tandem Mass Spectrometry (Monograph). VCH: New York, 1988.

25. Hunt, D. F. Yates, J. R., III;; Shabanowitz, J.; Winston, S.; Hauer, C. R. Protein Sequencing by Tandem Mass Spectrometry. Proc. Natl. Acad. Sci. U.S.A. 1986, 83, 6233-6237.

26. McLuckey, S. A.; Wells, J. M. Mass Analysis at the Advent of the 21st Century. Chem. Rev. 2001, 101, 571-606.
27. Senko, M. W.; Speir, J. P.; McLafferty, F. W. Collisional Activation of Large Multiply Charged Ions Using Fourier Transform Mass Spectrometry. Anal. Chem. 1994, 68, 28012808.

28. Turecek, F.; Drinkwater, D. E.; McLafferty, F. W. Gas-Phase Chemistry of $\mathrm{CH} 3 \mathrm{SOH},-\mathrm{CH}_{2}^{+} \mathrm{SHOH}, \mathrm{CH}_{3} \mathrm{SO}$, and ${ }^{\circ} \mathrm{CH}_{2} \mathrm{SOH}$ by Neutralization-Reionization Mass Spectrometry. J. Am. Chem. Soc. 1989, 111, 7696-7701.

29. Zubarev, R. A.; Kelleher, N. L.; McLafferty, F. W. Electron Capture Dissociation of Multiply Charged Protein Cations. A Nonergodic Process. J. Am. Chem. Soc. 1998, 120, 3265-3266.

30. Zubarev, R. A.; Kruger, N. A.; Fridriksson, E. K.; Lewis, M. A.; Horn, D. M.; Carpenter, B. K.; McLafferty, F. W. Electron Capture Dissociation of Gaseous Multiply-Charged Proteins is Favored at Disulfide Bonds and Other Sites of High Hydrogen Atom Affinity. J. Am. Chem. Soc. 1999, 121, 2857-2862.

31. Zubarev, R. A.; Horn, D. A.; Fridriksson, E. K.; Kelleher, N. L.; Kruger, N. A.; Lewis, M. A.; Carpenter, B. K.; McLafferty, F. W. Electron Capture Dissociation for Structural Characterization of Multiply Charged Protein Cations. Anal. Chem. 2000, 72, 563-573.

32. Horn, D. M. Ge, Ying,; McLafferty, F. W. Activated Ion Electron Capture Dissociation for Mass Spectral Sequencing of Larger (42 kDa) Proteins. Anal. Chem. 2000, 72, 4778-4784.

33. McLafferty, F. W.; Horn, D. M.; Breuker, K.; Ge, Y.; Lewis, M. A.; Cerda, B.; Zubarev, R. A.; Carpenter, B. K. Electron Capture Dissociation of Gaseous Multiply Charged Ions by Fourier-Transform Ion Cyclotron Resonance. J. Am. Soc. Mass Spectrom. 2001, 12, 245-249.

34. Ge, Y.; Lawhorn, B. G.; El-Naggar, M.; Strauss, E.; Park, J-H.; Begley, T. P.; McLafferty, F. W. Top Down Characterization of Larger Proteins (45 kDa) by Electron Capture Dissociation Mass Spectrometry. J. Am. Chem. Soc. 2002, 124, 672-678.

35. Sze, S. K.; Ge, Y.; Oh, H-B.; McLafferty, F. W. Top-Down Mass Spectrometry of a 29-kDa Protein for Characterization of Any Posttranslational Modification to Within One Residue. Proc. Natl. Acad. Sci. U.S.A. 2002, 99(4), 1774-1779.

36. Fenn, J. B.; Mann, M.; Meng, C. K.; Wong, S. F.; Whitehouse, C. M. Electrospray Ionization for Mass Spectrometry of Large Biomolecules. Science 1989, 246, 64-71.

37. Marshall, A. G.; Hendrickson, C. L.; Jackson, G. S. Fourier Transform Ion Cyclotron Resonance Mass Spectrometry: A Primer. Mass Spectrom. Rev. 1998, 17, 1-36.

38. Little, D. P.; Speir, J. P.; Senko, M. W.; O'Connor, P. B.; McLafferty, F. W. Infrared Multiphoton Dissociation of Large Multiply Charged Ions for Biomolecule Sequencing. Anal. Chem. 1994, 66, 2809-2815.

39. Kelleher, N. L.; Zubarev, R. A.; Bush, K.; Furie, B.; Furie, B. C.; McLafferty, F. W.; Walsh, C. T. Localization of Labile Posttranslational Modifications by Electron Capture Dissociation: The Case of $\gamma$-Carboxyglutamic Acid. Anal. Chem. 1999, 71, $4250-4253$.

40. Stenballe, A.; Jensen, O. N.; Olsen, J. V.; Haselmann, K. F.; Zubarev, R. A. Electron Capture Dissociation of Singly and Multiply Phosphorylated Peptides. Rapid Commun. Mass Spectrom. 2000, 14, 1793-1800.

41. Shi, S. D. H.; Hemling, M. E.; Carr, S. A.; Horn, D. M.; Lindh, I.; McLafferty, F. W. Phosphopeptide/Phosphoprotein Mapping by Electron Capture Dissociation Mass Spectrometry. Anal. Chem. 2001, 73, 19-22.

42. Mirgorodskaya, E.; Roepstorff, P.; Zubarev, R. A. Localization of O-Glycosylation Sites in Peptides by Electron Capture Dissociation in a Fourier Transform Mass Spectrometer. Anal. Chem. 1999, 71, 4431-4436.

43. Håkansson, K.; Cooper, H. J.; Emmett, M. R.; Costello, C. E.; Marshall, A. G.; Nilsson, C. L. Electron Capture Dissociation and Infrared Multiphoton Dissociation MS/MS of an N- 
Glycosylated Tryptic Peptide to Yield Complementary Sequence Information. Anal. Chem. 2001, 73, 4530-4536.

44. Guan, Z. Identification and Localization of the Fatty Acid Modification in Ghrelin by Electron Capture Dissociation. J. Am. Soc. Mass Spectrom. 2002, 13, 1941-1945.

45. Wilm, M. S.; Mann, M. Analytical Properties of the Nanoelectrospray Ion Source. Anal. Chem. 1996, 68, 1-8.

46. Winger, B. E.; Campana, J. E. Characterization of Combinatorial Peptide Libraries by Electrospray Ionization Fourier Transform Mass Spectrometry. Rapid Commun. Mass Spectrom. 1996, 10, 1811-1813.

47. Marshall, A. G.; Wang, T. C. L.; Ricca, T. L. Tailored Excitation for Fourier Transform Ion Cyclotron Resonance Mass Spectrometry. J. Am. Chem. Soc. 1985, 107, 7893-7897.

48. Gauthier, J. W.; Trautman, T. R.; Jacobson, D. B. Sustained Off-Resonance Irradiation for Collision-Activated Dissocia- tion Involving Fourier Transform Mass Spectrometry. Collision-Activated Dissociation Technique that Emulates Infrared Multiphoton Dissociation. Anal. Chim. Acta 1991, 246, 211-225.

49. Cooper, H. J.; Hudgins, R. R.; Håkansson, K.; Marshall, A. G. Characterization of Amino Acid Side Chain Losses in Electron Capture Dissociation. J. Am. Soc. Mass Spectrom. 2002, 13, 241-249.

50. Loo, J. A.; Edmonds, C. G.; Udseth, H. R.; Smith, R. D. Effect of Reducing Disulfide-Containing Proteins on Electrospray Ionization Mass Spectra. Anal. Chem. 1990, 62, 693-698.

51. Axelsson, J.; Palmblad, M.; Håkansson, K.; Håakansson, P. Electron Capture Dissociation of Substance P Using a Commercially Available Fourier Transform Ion Cyclotron Resonance Mass Spectrometer. Rapid Commun. Mass Spectrom. 1999, $13,474-477$. 